desired: teaching from texts; big and im personal lecture courses; objective tests; dull teachers who, according to Professor William C. Steere, inspired one student at Michigan to write: "Every student has some small spark of genius. It is the duty of the professor to water this spark."

August Heckscher speaks of how the break-up of Community and the disintegration of Authority have affected book reading. The problem is then examined from the viewpoint of the teacher: Professor Reuben A. Brower of Harvard in discussing the humanities arouses much discussion about his techniques of "reading in slow motion." The social sciences are covered by Professor Robert C. Angell of Michigan, and the sciences by Dr. Steere. Harold Guinzburg, publisher, and Ralph E. Ellsworth, librarian, put stress on the importance of the accessibility of books through a college bookstore and library.

Many ways to encourage more book reading are suggested by the conferees. Several quote approvingly the recommendation of the President's Committee on Education Beyond the High School: "The Committee particularly urges increasing emphasis on the development of educational methods which place larger responsibility for learning on the student himself." This should force the undergraduate to turn more to the library and independent reading. Dr. Ellsworth emphasizes that the library must have the support of the college administration in order to have the proper staff and resources to meet such demands. All agree, however, that incentive must be supplied by devoted teachers and effective teaching methods.

What, then, is discouraging about this symposium? Briefly, it is the discrepancy between the ideal solutions offered here and the harsh reality of the formidable obstacles blocking the way to any practicable accomplishment. Previous studies by Dr. Patricia Knapp and testimony by teachers at this conference indicate that the laudable objectives of the institution with regard to promoting lifetime reading interests are often at variance with the aims of a particular instructor who is concerned with inculcating a narrowly defined body of knowledge. Mrs. Roberta Keniston, librarian of the Michigan undergraduate library, warns that the library had better not try to dictate to the faculty how courses should be taught. Furthermore, Dean Roger Heyns of Michigan admits that "many of the most conscientious university teachers today are not fully convinced about the primary place of reading in the learning process."

Finally, several conferees stress the great importance of motivation in reading: motivation which is dependent upon the status of the scholar, intellectual (egg-head), and bookworm in American society. Unless the library can be made to seem as important and acceptable to the undergraduate as the student union, football, fraternities, and other symbols of social standing, book reading will be a minority activity. Can librarians make reading glamorous? Can they persuade teachers to stress the book? Can they inspire lifelong enthusiasm for book reading? If not, who will?

Dean Asheim concludes with the admonition that for college teachers, administrators, and librarians to read this stimulating book is not enough. Book reading must lead to book use, and achievement of some of the challenges in this book "can come only through constructive action, action stimulated and given direction by the ideas recorded here."-Henry James, Jr., Ferguson Library, Stamford, Conn.

\section{Mean What You Say}

Mean What You Say: Proceedings of a Conference on Written and Oral Library Reporting at the University of California, Santa Barbara, July 20-23, 1958. . . Ed. by Betty Rosenberg. (UCLA Library Occasional Papers, Number 10.) Los Angeles: University of California Library, 1959. xii, 85p.

"I think of this conference as a conspiracy, bent on overthrowing the dullness, ambiguousness, formlessness, verboseness, jargon, that keep librarians from effectiveness when they write and speak. ... This is no light task. We are like Xenophon's Greeks, deep in the desert, ringed by laziness, indifference, fear, even despair, and the blue water is far away."

With these eloquent words (p. 2) Lawrence Clark Powell opened this conference. Anyone who has ever plodded through that

COLLEGE AND RESEARCH LIBRARIES 
vast wasteland which librarians, with unconscious humor, call "The Literature" will agree that there is need for such a task, and that the task is not light.

But Xenophon had one advantage: $\mathrm{His}$ little band were experts, tough Greek soldiers who knew what they wanted and how to get it.

"Mean what you say," Betty Rosenberg named the conference, and she explained the title with a story (p. viii):

"Then you should say what you mean," the March Hare went on.

"I do," Alice hastily replied; "at leastat least I mean what I say-that's the same thing, you know."

"Not the same thing a bit!" said the Hatter. "Why, you might just as well say that 'I see what $I$ eat' is the same thing as ' $I$ eat what I see'."

The Hatter won the prize, but Alice named the conference.

Indeed, the story was introduced with a sentence on the "difficulty of making words say what we mean or mean what we say." Are the two, then, after all, identical? Apparently not, for later (p. 24 and 25) Miss Rosenberg cites with approval Sir Ernest Gowers (elsewhere, p. ix, called "Gower"): "Very few can write what they mean. ..." It seems that the giant "Ambiguousness" has yet to be overthrown.

Several misfortunes befell this latter day Anabasis.

For one thing there is language: "this trending period" (p. 17); "research-type libraries" (p. 32); "public-type library" (p. $32)$; "precipitate" apparently intended to mean "work its way down" (p. 54); "lengthen it out" (p. 61).

Occasionally there are awkward clauses or sentences. "Now there is a great urge on the part of editors, for myself also [why the 'for'?] to publish fine writing. . . . Literature with a capital ' $L$ '. Once in a while we have one [one what?] which we feel we can use" (p. 22). “. . . I'm very much disgusted when they don't have in them exactly what I want, like, for instance, how long is the children's book room open" (p. 36). “... There is nothing about scholarly writing that excludes liveliness and interest, except the intent of the writer" (p. 37). Does this mean that the intent of the author always or only sometimes (perhaps because of thoughtlessness) ex- cludes liveliness and interest? In any event, the next paragraph praises the grace and economy of academic writing, concluding that "This writing is not lacking in surprise and excitement-good, simple, economical, sparse sentences lack excitement only if the matter is dull." In this sentence "surprise" and "excitement" overlap in meaning, as do also "good, simple, economical, sparse"; is, then, economy a virtue not needed in librarians' writing? "I know of no library, great or small-and I have been in hundreds with my feelers sensitive to this problem to a degree you would not believe possible if you did not know me so well, with my antenna plugged in and the communication really coming through-I know of no library which ..." (p. 54).

These words and phrases and sentences are not necessarily incorrect, and certainly they can be understood. But it is a bit surprising to find them on the lips of Caesar's wives.

Gobbledegook is properly denounced (p. ix), yet the only instance cited is curiously enough not from library literature, but "a classic example ... found in Dwight MacDonald's history of the Ford Foundation." (Apparently if you mean what you say you need not give exact title, date, and page when you refer to a passage from a book; for pedants like the author of this review the details are here added: The Ford Foundation, the Men and the Millions (1956), pp. 105-106.) This example may be "classic" but its "gobbledegook" is sometimes quite intelligible, and the "translation" seldom translates-e.g., "The first phase had consisted of intensive exploratory studies of the adjustment of foreign students to life on American campuses.... As was hoped [Translation: We were disappointed], these studies ..." (p. $x$ ).

In some of the papers the dash is ubiquitous; on page 38 , for instance, there are seventeen dashes.

Something perhaps akin to the "formlessness" denounced on page 2 appears on page 8 , when we are urged in some detail to "have something which will be of profit to those who will hear or read it"-a splendid idea, albeit somewhat elementary. But the writer had already developed this theme at some length on page 5 and had then moved on to something else. Again, on page 12 we 
read: "Ephesians 4:29 tells us: 'Let no corrupt communication proceed out of your mouth, but that which is good.' In other words, we can only take out of the treasure chest what is in it." Is this really the Ephesians passage "in other words"?

The fact that the editor of a staff bulletin does not "get much comment from within the library" sometimes "worries the editor because he wonders if anybody is reading his publication. . . . Is it really necessary? Is it interesting ... . ? Could it be dropped and nobody notice it? Most of these questions never get answered, and it's just as well for the editor not to worry about them. ..." (p. 42). Why is it "just as well"? Surely, if he were at all concerned about the theme of this conference, he would give much thought to these matters.

"There was so much to talk about and be controversial about that somehow we did not get down to 'how-to' mean what you say" (p. 84). And yet there was time for things not even remotely connected with the grand "conspiracy" announced on page 2e.g., the emphasis on being sure to sign the library report (p. 34) or to name the library and (often) the place in which the library is located-"If you should happen to be operating a library called the Los Angeles Public Library in San Francisco, it would be important to add the city" (p. 37) -; and the instructions on not merely how to make a

\section{Comment}

\section{Research and Reality}

In the September 1959 issue of CRL Robert E. Dysinger of Bowdoin, writing on "The Research Library in the Undergraduate College," tells us that ". . . a collection which reflects the curriculum of the institution and the interests of individual scholars and is well selected and thinned will bulk large and have far in excess of 250,000 volumes." By an interesting coincidence, CRL statistics for $1957 / 58$ show that Bowdoin just happens to have had 249,564 volumes in its library at that time. talk but also how to get to be invited to make a talk (p. 56) and how to dress for the occasion-"If you wear a corsage, and a pin, and several other assorted trimmings, you will be a distraction to the audience" (p. 62).

It is hard to escape the feeling that somehow some of the sessions may have slipped into the "Sin of Verbosity. Too much is said, too much is written about too little" (p. 5).

The book is a "transcript from tape, somewhat revised and abridged ..." (p. vii). In a conference whose "goal is clear thinking, precise writing and speaking" (p. 2) one would expect papers carefully written and revised by their authors before they were presented and carefully revised again by the editor before they were published. We are indeed "ringed by laziness" (p. 2).

And yet, perhaps, it was a notable conference, if for no other reason than that it tackled, however inadequately, a major problem whose very existence often goes without notice: Why cannot, or do not, librarians write readable prose? Some of the side issues raised are also notable-for instance (p. 8 and pp. 80-81) why do we have so little controversy if librarianship really means much to us? Finally some of the papers were excellent; Mr. Powell was eloquent, Mr. Malkin was stimulating, and $\mathrm{Mr}$. Lubetzky was lucid and brief.-Paul S. Dunkin, Rutgers University.
At the same time, the median figure for Group II college libraries in the same set of statistics shows 130,284 volumes. At the median rate of increase, as of $1957 / 58,5,151$ books per year, it would take almost a quarter-century to reach the figure Mr. Dysinger indicates as a minimum figure, 250,000 volumes.

Why is there any feeling, in this day of ready accessibility of needed volumes and pages, through interlibrary loan and modern copying methods, that the undergraduate college library must try to be what it can

COLLEGE AND RESEARCH LIBRARIES 